DOI 10.15290/cnisk.2020.01.08.10

AGNIESZKA DROZDOWSKA

https://orcid.org/0000-0003-2713-7958

Uniwersytet w Białymstoku

\title{
Liderki Ligi Kobiet Polskich wobec wyborów w latach 80. (w świetle „Naszej Pracy”) ${ }^{1}$
}

\begin{abstract}
Streszczenie
Artykuł prezentuje postawę czołowych członkiń Ligi Kobiet Polskich wobec wyborów parlamentarnych, rozpowszechnianą na łamach miesięcznika „Nasza Praca” w ostatniej dekadzie Polskiej Rzeczypospolitej Ludowej. Materiał źródłowy niniejszego artykułu pozwala wykazać nasilenie propagandy wyborczej w latach 1980, 1985 i 1989. Liderki masowej organizacji kobiecej starały się uzyskać poparcie kobiet poprzez uświadamianie im konieczności głosowania na kobiety w nadchodzacych wyborach parlamentarnych. Na łamach miesięcznika „Nasza Praca” domagały się równości płci, ukazywały sytuację społeczną kobiet oraz zalety wspólnego działania kobiet.

Słowa kluczowe: Liga Kobiet Polskich, organizacja kobieca, wybory parlamentarne, „Nasza Praca”
\end{abstract}

1 Artykuł przygotowany w ramach realizacji projektu badawczego Narodowego Centrum Nauki pt. Liga Kobiet w terenie. Działalność organizacji i realia jej funkcjonowania na szczeblu regionalnym i lokalnym w rzeczywistości Polski Ludowej (1945-1989), nr 2017/25/B/ HS3/02015. 


\title{
LEAGUE OF POLISH WOMEN LEADERS AND ELECTIONS IN THE 1980s (IN “OUR WORK")
}

\begin{abstract}
The article presents the attitudes of leading members of Liga Kobiet Polskich [League of Polish Women] to the parliamentary elections, published in the Nasza Praca [Our Work] monthly in the last decade of the Polish People's Republic. The source material for this article can be found in the election propaganda in 1980, 1985, and 1989. The leaders of the mass women's organization attempted to get access to women by voting for women in the upcoming parliamentary elections. In the Nasza Praca monthly, they postulated gender equality, they showed the social situation of women and the advantages of a women's joint action.
\end{abstract}

Keywords: League of Polish Women, women's organization, parliamentary elections, Nasza Praca [Our Work]

\section{Wprowadzenie}

Pismo „Nasza Praca” od marca 1947 r. do grudnia 1980 r. było biuletynem informacyjnym Ligi Kobiet² ${ }^{2}$ W roku 1980 i od lipca 1989 r. był to dwumiesięcznik. W styczniu 1981 r. redakcja pisma poinformowała czytelników o przełomie w wydawaniu „Naszej Pracy”, która z „wewnętrznego biuletynu o charakterze instruktażowym staje się ... oficjalnym miesięcznikiem Zarządu Głównego Ligi Kobiet Polskich"3. Rzeczywiście starano się zachować częstotliwość ukazywania się pisma, choć w okresie wakacyjnym (lipiec-sierpień) najczęściej ukazywał się jeden numer. Wydawca pisma od 1981 r. był RSW „Prasa-Książka-Ruch”. Nakład pisma w omawianym okresie wynosił 16500 egzemplarzy, a ostatni numer z 1989 r. już tylko 12 000. Prócz informacji na temat działalności organizacji w terenie, miesięcznik zawierał więcej treści o charakterze ogólnym, mogących zainteresować kobiety niezrzeszone w Lidze Kobiet. Wprowadzono nowe działy, m.in.: „Z życia rodziny”, „Kobieta w świecie”,

2 W latach 1945-1949 organizacja funkcjonowała pod nazwą Społeczno-Obywatelska Liga Kobiet (SOLK), od września 1949 do grudnia 1981 jako Liga Kobiet, a od 1982 jako Liga Kobiet Polskich.

3 "Od Redakcji”, Nasza Praca, nr 1, 1981, 1. Zmiana nazwy organizacji została uchwalona podczas VIII Nadzwyczajnego Zjazdu Ligi Kobiet trwającego w dniach 28-29 listopada $1981 \mathrm{r}$. 
„Kultura i oświata”, „Poznajemy prawo”, „Komitet Gospodarstwa Domowego radzi" ". Od 1982 roku jeden numer pisma co roku ukazywał się z podtytułem „Poradnik metodyczny”, w którym wzorem początkowych numerów biuletynu, publikowano wyłącznie cele i zasady działania organizacji w terenie. Główne tematy poruszane na łamach miesięcznika w latach 80. dotyczyły promowania rozbrojenia i pokoju na świecie oraz wychowania społeczeństwa w duchu socjalizmu ${ }^{5}$.

Zmiana charakteru pisma wynikała ze złej sytuacji gospodarczej, społecznej i politycznej kraju. W 1981 r. odbył się VIII Nadzwyczajny Zjazd Ligi Kobiet, podczas którego podjęto uchwałę o zmianie nazwy organizacji na Ligę Kobiet Polskich, w celu podkreślenia jedności organizacji z Polkami ${ }^{6}$. W czasie Zjazdu krytykowano bierna postawę członkiń organizacji podczas strajków na Wybrzeżu i w Łodzi, choć nie oznaczało to poparcia dla opozycji rządowej ${ }^{7}$. Przez cały bowiem okres Polski Ludowej Liga Kobiet stanowiła zaplecze propagandowe Polskiej Zjednoczonej Partii Robotniczej8.

Tytułowymi liderkami Ligi Kobiet były czołowe działaczki organizacji, które zazwyczaj zajmowały najważniejsze stanowiska w Zarządzie Głównym i zarządach wojewódzkich Ligi Kobiet. W niniejszym opracowaniu pojęcie to obejmuje jedynie członkinie Zarząu Głównego, ponieważ to one właśnie publikowały na łamach „Naszej Pracy” nieliczne artykuły dotyczące wyborów parlamentarnych.

Wybory parlamentarne w omawianym okresie odbyły się 23 marca 1980 r., 13 października 1985 r. oraz 4 i 18 czerwca 1989 r. ${ }^{9}$ Analiza

\footnotetext{
4 Ibidem.

5 Danuta Markowska, „O wychowaniu dla przyszłości”, Nasza Praca, nr 3, 1980, 64-71; Irena Hamerska, „Cel - dalsza edukacja kobiet”, Nasza Praca, nr 3, 1980, 31-35; Eugenia Kempara, „Przeciwko faszyzmowi - za pokojem i rozbrojeniem”, Nasza Praca, nr 4, 1980, 3-6; Maria Regent-Lechowicz, „Wychowanie dla pokoju”, Nasza Praca, nr 4, 1980, 7-14; Melania Mroczek-Szymańska, „Kobiety polskie w zwycięstwie nad faszyzmem i w walce o pokój”, Nasza Praca, nr 4, 1980, 15-26.

6 Agnieszka Drozdowska, „Działalność Ligi Kobiet w północno-wschodnich terenach Polski Ludowej w latach 1975-1989 w świetle "Naszej Pracy»", Niepodległość i Pamięć. Czasopismo humanistyczne, R. XXVI, nr 2(66), 2019, 190.

7 Emilia Świętochowska, „Sytuacja społeczno-zawodowa kobiet $w$ ostatniej dekadzie $P R L "$, w: Ewa Chabros, Agnieszka Klarman (red.), Kobiety na zakręcie 1933-1989, (Wrocław: IPN, 2014), 302.

8 Anna Marcinkiewicz-Kaczmarczyk, „Rola Ligi Kobiet w popularyzowaniu polityki władz "Polski Ludowej”", Dzieje Najnowsze, Vol 50, nr 2, 2018, 283-301.

9 Zob. Małgorzata Dajnowicz, „Zwierciadło” - platforma polityczna Ligi Kobiet w okresie PRL (1957-1961, 1982-1989)", Rocznik Historii Prasy Polskiej, t. XX, z. 3(47), 2017, 67-90;
} 
miesięcznika udowodniła, że problematyka wyborów parlamentarnych poruszana była na łamach pisma w dość niedużym stopniu i wyłącznie $\mathrm{w}$ niewielkim odstępie czasowym od daty przeprowadzenia wyborów.

\section{Rok 1980}

W wyborach przeprowadzonych 23 marca 1980 r. do Sejmu PRL aż 106 kobiet dostało mandat poselski. Informacja na temat wyborów parlamentarnych pojawiła się $\mathrm{w}$ drugim numerze pisma. Opublikowano wówczas referat Eugenii Kempary - przewodniczącej Zarządu Głównego Ligi Kobiet oraz Krajowej Rady Kobiet Polskich, wygłoszony podczas sesji plenarnej Ogólnopolskiego Komitetu Frontu Jedności Narodu, tj. 21 lutego 1980 r., w którym padły słowa: „Sesja uchwaliła Deklarację Wyborcza FJN, której podstawą są uchwały VIII Zjazdu PZPR"10. Przewodnicząca przedstawiła w nim zależności między postawą kobiet pracujących w różnych zawodach a rozwojem kraju. Podkreślała znaczenie pracy kobiet dla dobra i rozwoju społeczeństwa. Całkowicie popierając uchwały VIII Zjazdu partii dotyczace m.in. przerwania wyścigu zbrojeń i zapewnienia pokoju na świecie, Eugenia Kempara uświadamiała kobiety o słuszności głosowania zgodnie $z$ linia partii komunistycznej. Jej referat zakończył się słowami: „Od urn wyborczych pójdziemy ze świadomością naszego miejsca w realizacji uchwał Zjazdu i naszych obywatelskich zadań. Zademonstrujemy jedność myśli i narodu"11.

W kolejnym numerze pisma przedstawiono wytyczne, jakie winny podejmować członkinie ruchu kobiecego przed wyborami $1980 \mathrm{r}$. Wśród nich było m.in. współdziałanie środowisk kobiecych, zacieśnianie współpracy między organizacjami kobiecymi i społecznymi oraz instytucjami, samorządem mieszkańców, współdziałanie $z$ radiem i telewizją.

eadem, „Kobiety - polityka - wybory w świetle "Zwierciadła: Pisma Ligi Kobiet Polskich" (1982-1989)”, w: Grzegorz Radomski, Michał Strzelecki, Katarzyna Sopolińska (red.), Rzeczpospolita w koncepcjach polskich partii $i$ środowisk politycznych XX $i$ XXI wieku, (Toruń: Wydawnictwo Naukowe Uniwersytetu Mikołaja Kopernika, 2018), 107-125; Urszula Ćwik, „Wybory parlamentarne i wybory do rad narodowych w Polskiej Rzeczpospolitej Ludowej na łamach "Kobiety i Życia" (do 1989 roku)", w: Małgorzata Dajnowicz, Adam Miodowski (red.), Polityka i politycy $w$ prasie XX i XXI wieku, (Białystok: Wydawnictwo Humanica, 2016), 328-337.

10 "Czujemy się adresatkami wszystkich zadań zawartych w uchwałach zjazdowych”, $\mathrm{Na}$ sza Praca, nr 2, 1980, 3.

11 Ibidem, 8. 
Ponadto zaznajomienie jak najwięcej kobiet $\mathrm{z}$ zaletami realizacji uchwał VIII Zjazdu PZPR. W numerze tym wskazano bezpośrednio, na kogo należy głosować: „Nasz patriotyzm, poparcie dla partii i chęć współuczestniczenia w realizacji jej programu zademonstrujemy 23 marca powszechnym udziałem w wyborach do Sejmu i wojewódzkich rad narodowych i oddaniem głosów na kandydatów Frontu Jedności Narodu" ${ }^{\prime 2}$.

Zastanawiające jest, że wyniki wyborów parlamentarnych $1980 \mathrm{r}$. nie zostały w żaden sposób omówione na łamach biuletynu ${ }^{13}$. Wyniki wyborów do Sejmu VIII kadencji zostały wspomniane przy podsumowaniu wyborów z 1985 i 1989 r. $^{14}$

Pismo z 1980 r. nie zawiera również zbyt wielu informacji na temat wydarzeń politycznych w kraju. Jednak panująca wówczas atmosferę w organizacji oddają artykuły, podkreślające konieczność zwiększenia poparcia społecznego i odzyskania wiarygodności programu partii komunistycznej, zachwianej przez strajki społeczne ${ }^{15}$.

\section{Rok 1985}

W roku 1985 Liga Kobiet Polskich obchodziła 40-lecie istnienia organizacji. Jak zapowiadano, na łamach miesięcznika pojawiać się miały artykuły poświęcone historii rozwoju organizacji oraz wywiady i biogramy zasłużonych działaczek Ligi ${ }^{16}$. W przeciwieństwie do poprzednich jubileuszy miał to być rok przemyśleń nad działalnością organizacji i powrót do tradycji. Nieustalenie hasła obchodów jubileuszu miało stanowić potwierdzenie swobody działania członkiń. „Hasła mają to do siebie, że schematyzuja i narzucaja jednolity sposób myślenia. Nie o to przecież chodzi. Trzeba sięgać do różnorodności w tradycji organizacji, sięgać do tego, co już było i co ewentualnie można wykorzystać"17. W roku tym

\footnotetext{
12 „Plenum Krajowej Rady Kobiet Polskich przy Ogólnopolskim Komitecie FJN. Uchwała Krajowej Rady Kobiet Polskich", Nasza Praca, nr 3, 1980, 7.

13 „Kronika wydarzeń”, Nasza Praca, nr 4, 1980, 93-94.

14 Małgorzata Szczodrowska-Gąsior, „Kobiety w organach przedstawicielskich”, Nasza Praca, nr 7-8, 1989, 16-17.

15 Eugenia Kempara, „VI Plenum KC PZPR”, Nasza Praca, nr 6, 1980, 3-10; Weronika Jackowska, „Programowanie działań organizacji”, Nasza Praca, nr 6, 1980, 13-14, 26-27; Teresa Elmerych, „Kierunki działalności programowej w 1981 roku”, Nasza Praca, nr 5, 1980, 15-18.

16 „Od Redakcji”, Nasza Praca, nr 1, 1980, 1-2.

17 Elżbieta Karwacka, „Wczoraj i dziś”, Nasza Praca, nr 1, 1985, 9.
} 
przewodniczaca Ligi Kobiet Polskich - Jadwiga Biedrzycka, stwierdziła też, że organizacja nie jest reprezentantką wszystkich polskich kobiet, a jedynie tych zrzeszonych w organizacji ${ }^{18}$. Organizacja w 1985 r. zrzeszać miała 500 tys. członkin ${ }^{19}$.

Wśród sylwetek prezentowanych z okazji 40-lecia organizacji były m.in.:

- Eugenia Pragierowa - pierwsza wiceprzewodnicząca ZG SOLK, przewodnicząca Światowej Demokratycznej Federacji Kobiet oraz członkini Krajowej Rady Narodowej (1943-1947), posłanka Sejmu Ustawodawczego (1947-1952) oraz Sejmu PRL I kadencji (1952-1956).

- Regina Danysz-Fleszarowa - wiceprzewodniczaca Ligi Kobiet - senatorka RP IV kadencji 1935-1938 (wiceprezes Sadu Marszałkowskiego) „znana była ze swych odważnych wystąpień krytykujacych sanacyjna władzę za zwalnianie $z$ pracy zamężnych kobiet"20.

- Stanisława Garncarczyk - przewodnicząca Ligi Kobiet, posłanka z ramienia Stronnictwa Ludowego, „inicjowała formy działalności naszej organizacji w środowisku kobiet wiejskich. Była entuzjastką działań służących zbliżeniu kobiet wsi i miast"21.

- Edwarda Orłowska - wiceprzewodniczaca Ligi Kobiet, kierownik Wydziału Kobiecego KC PZPR, członkini Krajowej Rady Narodowej (19431947), posłanka Sejmu Ustawodawczego (1947-1952) oraz Sejmu PRL I kadencji (1952-1956), „żarliwie uczyła nasze działaczki myślenia politycznego, ukazywała im sens, cele i zadania ruchu kobiecego. Organizowała nasze spotkania $z$ najważniejszymi przedstawicielami partii" 22 .

- Izolda Kowalska - sekretarz ZG LK, członkini Krajowej Rady Narodowej (1943-1947), ,jej wielki talent organizacyjny, ogromna inwencja były wielce pomocne w procesie budowania Ligi jako ogólnopolskiej organizacji”23.

\footnotetext{
18 Ibidem, 11.

19 Ibidem, 12; Małgorzata Dajnowicz, „Liga Kobiet w terenie. Kierunki działalności organizacji na przykładzie struktur białostockich w latach 1966-1981", Niepodległość i Pamięć. Czasopismo humanistyczne, nr 2(62), 2018, 175.

20 „Sylwetki 40-lecia. Pamiętajmy o nich”, Nasza Praca, nr 1, 1985, 13.

${ }^{21}$ Ibidem, 14.

22 Ibidem.

${ }^{23}$ Ibidem.
} 
W zwiazku z 40. rocznica istnienia Ligi na łamach miesięcznika w dziale „Z historii ruchu ludowego w Polsce” pojawiały się informacje na temat zależności między polityka państwa a aktywnościa polityczna kobiet. Przypominano, że w pierwszej kadencji Sejmu PRL było 76 posłanek, a w drugiej tylko 19. Wspominano, że w roku 1980 organizacja bardzo starannie przygotowywała się do kampanii wyborczej do Sejmu i rad narodowych, m.in. poprzez organizowanie wykładów i spotkań organizacji, uświadamianie kobiet o działalności rad narodowych, tworzono listę kobiet przydatnych do ewentualnej działalności w radach ${ }^{24}$.

Pierwsza wzmianka na temat wyborów parlamentarnych $1985 \mathrm{r}$. pojawiła się w numerze szóstym. Sekcja Kobiet Prawników przy ZG LKP przypominała kobietom, że Konstytucja PRL z 22 lipca 1952 r. gwarantuje równe prawa kobietom i mężczyznom ${ }^{25}$. Podkreślano, że kobiety stanowiące połowę społeczeństwa, mogą tworzyć znacząca siłę w walce o równouprawnienie kobiet. Zachęcano kobiety do przemyślanych wyborów na kandydatów do Sejmu oraz aktywny udział w spotkaniach przedwyborczych w celu opracowania właściwego programu wyborczego, odpowiadającego oczekiwaniom społeczeństwa ${ }^{26}$.

„Kampania wyborcza do Sejmu PRL rozpoczęła się 10 czerwca br. [1985 r.] podjęciem uchwały Rady Państwa o zarządzeniu wyborów ...”27. W zwiazku z tym 24 czerwca 1985 r. odbyło się posiedzenie Prezydium ZG LKP, podczas którego przedstawiono zadania członkiń LKP w nadchodzacych wyborach. Przypomniano, że uzyskały po raz pierwszy prawo wysuwania osób na kandydatów na posłów, ,jako organizacja społeczna o zasięgu ogólnokrajowym. ... Ustalono, że rekomendacja członkiń LKP na kandydatki na posłanki wymaga uchwały Prezydium odpowiedniego zarządu wojewódzkiego, poprzedzonej szeroka konsultacja społeczna w środowisku, z którego wywodzi się kandydatka"28. Zarządy wojewódzkie powołały „zespoły działaczek do systematycznej współpracy z Radami PRON. ... Upowszechniano Ordynację Wyborcza do Sejmu PRL

\footnotetext{
${ }^{24}$ Romana Lewandowska, „Z historii ruchu kobiecego w Polsce. Sytuacja kobiet w Polsce w latach pięćdziesiątych", Nasza Praca, nr 4, 1985, 23-25.

25 Konstytucja Polskiej Rzeczypospolitej Ludowej z dnia 22.07.1952 r. [online] [dostęp: 3.07.2020]. Dostępna w World Wide Web: http://prawo.sejm.gov.pl/isap.nsf/download. xsp/WDU19520330232/O/D19520232.pdf.

26 Janina Polony, Danuta Trojnar, „Informujemy, radzimy, pomagamy... Sekcja Kobiet Prawników. Rozmyślania o obowiazkach obywatelskich”, Nasza Praca, nr 6, 1985, 38.

27 „Materiały i dokumenty. Od Redakcji”, Nasza Praca, nr 9, 1985, 1.

28 Ibidem, 1.
} 
i Deklarację Wyborcza PRON, omawiano prawa i obowiazki obywateli zwiazane $z$ aktem wyborczym"29. Członkinie LKP weszły w skład obwodowych i okręgowych Komisji Wyborczych. Zgodnie $z$ tymi ustaleniami w kolejnych miesiącach plena zarządów wojewódzkich LKP m.in. w Białymstoku, Krakowie, Bydgoszczy, Radomiu, Częstochowie, Rzeszowie i Wałbrzychu organizowały zebrania, na których zgłaszano kandydatki do Sejmu oraz omawiano zadania LKP w kampanii przedwyborczej ${ }^{30}$. Wśród 50 kandydatów na posłów $z$ listy PRON znalazła się Jadwiga Biedrzycka - ówczesna przewodnicząca ZG LKP. Po 7 sierpnia 1985 r. rozpoczęły się spotkania promujące sylwetki kandydatów na posłów ${ }^{31}$. Już pierwszy artykuł tego numeru apelował o jedność społecznego działania, która zapewni „pokojowy, dostatni i praworzadny byt”32. O spotkaniu Romualdy Matusiak - kandydatki do Sejmu i posłanki IX i X kadencji $z$ wyborcami w Koninie, poinformował w grudniowym numerze „Naszej Pracy" tamtejszy Zarząd Wojewódzki LKP. Posłanka rozmawiała wówczas o potrzebach i problemach ówczesnych kobiet ${ }^{33}$.

Wybory do Sejmu IX kadencji odbyły się 13 października 1985 r. W gronie 450 posłów wybrano 93 kobiety, a wśród nich 39 należało do Ligi Kobiet Polskich. „W czasie pierwszego posiedzenia Sejmu - 6 listopada 1985 r. - Jadwiga Biedrzycka, przewodniczaca ZG LKP została wybrana na wicemarszałka Sejmu, a Elżbieta Łucja Gacek, przewodniczaca ZM LKP w Kielcach - na członkinię Rady Państwa"34. Dopiero przy omawianiu bieżących wyników wyborów po raz pierwszy odwołano się do poprzedniej kadencji, w której mandat poselski zdobyło 106 kobiet. Redakcja pisma zadała wówczas retoryczne pytanie: „Czy [różnica ta] powinna nas martwić?”. W dalszej części artykułu poinformowano czytelniczki o skali zaangażowania członkiń Ligi w przeprowadzonych wyborach. „Około dwustu naszych działaczek weszło w skład okręgowych komisji wyborczych, około pięciu tysięcy w skład obwodowych komisji, a 131 w skład wojewódzkich konwentów. Członkinie LKP były też mężami zaufania przy organach wyborczych ..." ${ }^{35}$.

\footnotetext{
29 Ibidem, 2.

30 Regina Jaskółkowska, „Kronika wydarzeń”, Nasza Praca, nr 11, 1985, 32; eadem, „Kronika wydarzeń”, Nasza Praca, nr 12, 1985, 32.

31 „Materiały i dokumenty. Od Redakcji”, Nasza Praca, nr 9, 1985, 2.

32 Dariusz Gierycz, „Potrzebna jedność działania”, Nasza Praca, nr 9, 1985, 3-6.

33 „Z pracy kół i zarządów”, Nasza Praca, nr 12, 1985, 31.

34 „Od redakcji”, Nasza Praca, nr 11, 1985, 1.

35 Ibidem, 2.
} 


\section{Rok 1989}

Rok 1989 był przełomowy w dziejach Polski. Na przewodnicząca ZG LKP została wybrana Elżbieta Lęcznarowicz ${ }^{36}$, dotychczasowa przewodniczaca ZW LKP w Krakowie ${ }^{37}$. Organizacja zrzeszać miała wówczas 585550 kobiet $^{38}$. Kolejna, X kadencja Sejmu rozpoczęła się w czerwcu 1989 r. Jak zapowiadano na łamach miesięcznika, „Opracowana zostanie nowa ordynacja wyborcza, rezygnujacca $z$ plebiscytowego charakteru wyborów i urzędniczej ingerencji w tryb ustalania kandydatur. Przedstawicielom opozycji zostanie umożliwione ... wejście do parlamentu w uprzednio ustalonej formie i liczbie"39.

Spotkania posłanek $z$ członkiniami LKP odbywały się zarówno w trakcie kampanii wyborczej, jak i po jej zakończeniu. O wizycie w Kielcach (22 listopada 1988 r.) Elżbiety Gacek ${ }^{40}$ - wicemarszałka Sejmu i wiceprzewodniczacej ZG LKP, poinformowano w dziale „Przegląd prasy”. Jej wizytę odnotowała lokalna prasa ${ }^{41}$. Kolejne spotkanie Elżbiety Gacek z ZW LKP w Kielcach odbyło się w marcu 1989 r. Zachęcała ona członkinie organizacji do aktywnej kampanii wyborczej i dalszej współpracy $z$ posłankami ${ }^{42}$. Natomiast o udziale posłanki Gertrudy Orlacz w posiedzeniu ZW LKP w Białymstoku w marcu 1989 r., poinformował sam Zarząd Wojewódzki LKP ${ }^{43}$.

Elżbieta Gacek informowała prasę o działaniach zwiazanych ze zmiana treści ordynacji wyborczej i zasad wyłaniania kandydatów do obu Izb. „Podział polityczny mandatów odbywa się tylko w odniesieniu do wyborów do Sejmu, w przypadku wyborów do Senatu nie ma takiego podziału. W przyszłym parlamencie będzie zasiadać 460 posłów i 100 senatorów" ${ }^{\prime 4}$.

\footnotetext{
36 Małgorzata Dajnowicz, „Posłanki Ligi Kobiet Polskich i wybory parlamentarne 1989 roku (prezentacja w świetle "Zwierciadła»", w: Małgorzata Dajnowicz, Adam Miodowski (red.), Polityka i politycy $w$ prasie XX $i$ XXI wieku. Polityka w prasie kobiecej, (Białystok: Wydawnictwo Uniwersytetu w Białymstoku, 2019), 210.

37 „Od redakcji”, Nasza Praca, 1989, nr 3, 1; „Elżbieta Lęcznarowicz - przewodniczaca Zarządu Głównego Ligi Kobiet Polskich”, Nasza Praca, nr 3, 1989, 6-7.

38 „Liga Kobiet Polskich w liczbach”, Nasza Praca, nr 4, 1989, 15.

39 Dariusz Ostrowski, „Rok 1989”, Nasza Praca, nr 2, 1989, 3.

40 Małgorzata, Dajnowicz. „Posłanki Ligi Kobiet Polskich”, 210.

41 „Przegląd prasy”, Nasza Praca, nr 2, 1989, 40.

42 „Z pracy kół i zarządów”, Nasza Praca, nr 4, 1989, 42.

43 Ibidem, 41.

44 Ibidem, 45.
} 
W „Przeglądzie prasy” redakcja miesięcznika informowała o, jej zdaniem, najbardziej interesujacych kobiety artykułach. W kwietniu 1989 r. w „Trybunie Ludu” pojawiła się informacja na temat utworzenia Komisji Porozumiewawczej Środowisk Kobiecych ds. Wyborów, która wystawić miała wspólną listę kandydatek do parlamentu. W piśmie opublikowano Apel wyborczy kobiet, a w numerze majowym krajowa listę wyborczą kandydatów na posłów. Na osiemnastej pozycji znalazła się przewodnicząca ZG LKP - Elżbieta Lęcznarowicz ${ }^{45}$, która nie uzyskała mandatu poselskiego.

Liga Kobiet Polskich wśród głównych kierunków działania organizacji w 1989 r. zapowiadała czynny udział w kampanii wyborczej do Sejmu i rekomendowanie swoich kandydatek ${ }^{46}$. W tym samym numerze pojawił się artykuł poświęcony polityce socjalnej PRL, w którym przedstawiono stanowisko organizacji wobec m.in. zasiłków wychowawczych, rent inwalidzkich czy emerytur ${ }^{47}$. Podczas posiedzenia ZG LKP w styczniu 1989 r., na którym obecny był m.in. sekretarz KC PZPR - Leszek Miller, poinformowano o konieczności wysuwania kandydatek do Sejmu, ale także popierania w wyborach kobiet niezrzeszonych w Lidze, ale posiadających kompetencje i umiejętności pozwalające walczyć o prawa kobiet $^{48}$. Zmiana podejścia wobec pochodzenia i przynależności organizacyjnej potencjalnych przyszłych posłanek stanowiła element przemian zachodzacych w Lidze. Otwartość i rzekome poparcie Ligi wobec wszystkich kandydatek do parlamentu miały wzbudzić w kobietach przekonanie, że głównym celem Ligi Kobiet była poprawa warunków życia wszystkich Polek.

W trzecim numerze „Naszej Pracy” z 1989 r. opublikowano wywiad $z$ wiceprzewodnicząca ZG LKP (od października 1986 r.) i wicemarszałkiem Sejmu (od czerwca 1988 r.) - Elżbieta Gacek, która opisała, na czym polega praca w Sejmie - najważniejsze powinno być dobro ogółu, a nie tylko lokalnej społeczności, oraz wskazała ważność jedności działania kobiet w czasie wyborów ${ }^{49}$. Idea jedności była podkreślana podczas

45 „Przegląd prasy”, Nasza Praca, nr 6, 1989, 43.

46 "Główne kierunki działania Ligi Kobiet Polskich w 1989 r.”, Nasza Praca, nr 2, 1989, 7.

47 „Opinie Ligi Kobiet Polskich. Polityka socjalna PRL. Propozycje kierunków jej systemowych zmian”, Nasza Praca, nr 2, 1989, 13-17.

48 "Notatki z posiedzenia ZG LKP”, Nasza Praca, nr 3, 1989, 5.

49 Elżbieta Karwacka, „Co nam pomaga, a co przeszkadza”, Nasza Praca, nr 3, 1989, 14-20. 
całej kampanii wyborczej. Nie chodziło jedynie o jednomyślne oddanie głosów na kobiety, ale również o to, że wszystkie środowiska kobiece utworzyły Komisję Porozumiewawcza, która wysuwać miała najbardziej odpowiednie kandydatki na posłów i senatorów ${ }^{50}$.

W kwietniu 1989 r. ZG LKP opublikował Apel do kobiet, w którym podkreślano, że kobiety stanowią połowę społeczeństwa i powinny same walczyć o swe prawa. „O swoich sprawach chcemy mówić własnym głosem. Głosuj na nas!"51. O mandat poselski w wyborach 4 czerwca 1989 r. ubiegało się 179 kobiet, a o mandat senatorski 27. Ostatecznie do Sejmu dostały się 62 kobiety, a do Senatu 6. Ten, jak pisała redakcja „Naszej Pracy", skromny wynik miał być spowodowany słaba siła przebicia haseł wyborczych środowisk kobiecych. Zastanawiajace jest, dlaczego hasła wyborcze: „Kobieto! Daj szansę - wybierz swoje reprezentantki”, „Kto wie lepiej niż kobieta, czego potrzeba rodzinie”, „Wykorzystajmy wiedze i doświadczenie kobiet”, pojawiły się na łamach miesięcznika dopiero po zakończonych wyborach. Jest to może potwierdzenie tezy, że miesięcznik „Nasza Praca” nie stanowił podstawowej platformy wyborczej kandydatek do Sejmu.

Artykuł powyborczy ze spotkania ZG LKP z Wojciechem Jaruzelskim i Leszkiem Millerem pokrótce omawiał wyniki wyborów i sytuację kobiet $^{52}$. Temat wyborów został poruszony również podczas spotkania ZG LKP z Radą Krajową Polskich Konsumentów. Sekretarz ZG LKP Elżbieta Dehnel-Łuszczyńska poinformowała o niezadowalającym wyniku wyborów. Wśród 62 kobiet, które uzyskały mandat poselski, było $45 \mathrm{z}$ mandatu koalicyjnego i 17 bezpartyjnych, kandydature $20 \mathrm{z}$ nich popierała LKP. Wśród 6 senatorek nie było żadnej przedstawicielki LKP53. Porażka wyborcza liderek Ligi Kobiet wynikać mogła m.in. $z$ braku zaangażowania się kobiet w życie polityczne. Niepewna sytuacja społeczno-polityczna kraju wzmagała wśród dotychczasowych członkiń LKP stan niepewności i wyczekiwania na rozwój sytuacji.

50 „Do wyborów wspólnie”, Nasza Praca, nr 4, 1989, 2; „Mało nas, mało nas radnych”, Nasza Praca, nr 4, 1989, 28.

51 „Apel do kobiet”, Nasza Praca, nr 4, 1989, 1.

52 „Jak przybliżyć rzeczywiste równouprawnienie - spotkanie Prezydium ZG LKP z Wojciechem Jaruzelskim", Nasza Praca, nr 7-8, 1989, 1.

53 „Kondycja gospodarstwa domowego - ważna dla całej gospodarki”, Nasza Praca, nr 7-8, 1989, 6-7. 
W pierwszym powyborczym numerze pisma w „Przeglądzie prasy” poinformowano o wywiadzie katowickiego "Wieczoru” oraz „Przyjaciółki” z przewodnicząca ZG LKP - Lęcznarowicz, w którym podniesiono kwestię niedostatecznego rozpowszechniania sylwetek kandydatek do parlamentu oraz nadmiernego obciażenia kobiet obowiązkami domowymi. Tuż przed wyborami Lęcznarowicz udzieliła wywiadu także Alicji Bińskiej $z$ „Kobiety i Życia”, w którym przyznała rację nt. konieczności stworzenia nowego modelu działania Ligi, zgodnego $z$ oczekiwaniami kobiet. W dalszej części przeglądu poinformowano, że w okresie przedwyborczym prasa centralna i regionalna drukowała listy członkiń Komisji Wyborczych. Wśród nich najczęściej nie było członkiń Ligi Kobiet ${ }^{54}$.

Pojawił się również artykuł w dziale „Poradnictwo językowe” zatytułowany „Parlament i związane $z$ nim słownictwo”, w którym przedstawiono rys historyczny demokracji i znaczenie słów takich jak Sejm, parlament ${ }^{55}$.

Artykuły powyborcze z 1989 r. często odwoływały się do wyników wyborów z poprzednich kadencji. Za wzór stawiały wyniki z 1980 r., kiedy do Sejmu weszło 106 kobiet. Stanowiły próbę znalezienia przyczyny niepowodzenia kampanii wyborczej 1989 r., upatrując jej w zniechęceniu, przemęczeniu kobiet i braku wiary we własne siły oraz stereotypach na temat roli kobiet w społeczeństwie ${ }^{56}$.

\section{Podsumowanie}

Podsumowując, należy stwierdzić, że przez cały okres istnienia LKP była ona zależna i poddana PZPR, o czym świadczą nie tylko głoszone hasła, ale także obecność przedstawicieli partii na zebraniach Ligi ${ }^{57}$. Na łamach „Naszej Pracy” kampania wyborcza toczyła się w bardzo niewielkim stopniu. Niewattpliwie miesięcznik nie stanowił podstawowej platformy wyborczej kandydatek na posłanki, o czym świadczy ukazywanie się z opóźnieniem artykułów o tematyce wyborczej. Nie zamieszczano w ogóle artykułów prezentujących sylwetki kandydatek ubiegających się

\footnotetext{
54 „Przegląd prasy”, Nasza Praca, nr 7-8, 1989, 44-46.

55 Józef Porayski-Pomsta, „Poradnictwo językowe. Parlament i związane $z$ nim słownictwo", Nasza Praca, nr 9-10, 1989, 29-32.

56 Małgorzata Szczodrowska-Gassior, „Kobiety w organach przedstawicielskich”, Nasza Praca, nr 7-8, 1989, 16-18.

57 „Notatki z posiedzenia ZG LKP”, Nasza Praca, nr 3, 1989, 4.
} 
o mandat poselski czy senatorski. Brak jest wskazania najbardziej aktywnych regionów Polski, skąd wystawiano najwięcej kandydatek, jak głosowano w poszczególnych regionach i jaka była frekwencja wyborcza. Najbardziej ożywioną dyskusję na łamach miesięcznika wywołały wyniki wyborów z 1989 r., na temat których dosyć dużo informacji podawano w dziale „Przegląd prasy”, w którym odsyłano czytelniczki do artykułów w innych pismach. Liderki Ligi Kobiet w nielicznych artykułach koncentrowały się na uświadomieniu kobietom możliwości poprawy warunków życia pod warunkiem zjednoczenia się w działaniu. Zachęcano kobiety do głosowania na kobiety, które jako jedyne najlepiej miały reprezentować ich potrzeby i troski.

Redakcja miesięcznika „Nasza Praca” ze względu na dosyć niskie grono odbiorców (nakład w granicach 12-16,5 tys. egzemplarzy) i profil pisma (charakter instruktażowy i ściśle podległy wytycznym PZPR) oraz cenzurę, nie podejmowała się prowadzenia kampanii wyborczej kandydatek do Sejmu i Senatu. Liga możliwość taką dawała na łamach bardziej poczytnych w społeczeństwie pism takich jak „Zwierciadło”, które było tygodnikiem Ligi Kobiet Polskich ${ }^{58}$. Organizacja kobieca, mimo oficjalnie głoszonych prób rozszerzenia swojej działalności i otwarcia się na kobiety niezrzeszone w Lidze, do końca wykazywała konformistyczna postawę wobec PZPR i krytyczną wobec przeciwnych ruchów społecznych, tj. „Solidarności".

Ponadto lata 80., a zwłaszcza wybory 1989 r., stanowiły schyłek zaufania kobiet wobec działalności Ligi, która przez cały okres PRL zależna była od partii rządzącej. Kryzys polityczny odcisną piętno na liczebności organizacji, która na początku lat 80. zrzeszała ponad 500 tys. kobiet, a w poczatku lat 90. zaledwie ok. 6 tys. kobiet ${ }^{59}$. Trudna sytuacja gospodarcza, społeczna i polityczna w kraju powstrzymywała Polki przed opowiadaniem się za Liga.

58 „Zwierciadło” od początku swego istnienia, tj. od 1957 r., było sojusznikiem Ligi Kobiet. To właśnie na łamach tego tygodnika organizacja kobieca prowadziła kampanię wyborcza członkiń Ligi oraz kandydatek z Komitetu Obywatelskiego „Solidarność”, które startowały w wyborach parlamentarnych. Więcej na ten temat zob. Małgorzata Dajnowicz, „Posłanki Ligi Kobiet Polskich", 205-215.

59 Ibidem, 214; Katarzyna Jurkowska, „Kłopoty z tożsamością, czyli Liga Kobiet Polskich”, Ośka, nr 2, 2000, 38. 


\section{Bibliografia}

\section{Źródła}

„Apel do kobiet”, Nasza Praca, nr 4, 1989, 1.

"Czujemy się adresatkami wszystkich zadań zawartych w uchwałach zjazdowych", Nasza Praca, nr 2, 1980, 3.

„Do wyborów wspólnie”, Nasza Praca, nr 4, 1989, 2.

Elmerych, Teresa. „Kierunki działalności programowej w 1981 roku”, Nasza Praca, nr 5, 1980, 15-18.

„Elżbieta Lęcznarowicz - przewodniczaca Zarządu Głównego Ligi Kobiet Polskich", Nasza Praca, nr 3, 1989, 6-7.

Gierycz, Dariusz. „Potrzebna jedność działania”, Nasza Praca, nr 9, 1985, 3-6. "Główne kierunki działania Ligi Kobiet Polskich w 1989 r.", Nasza Praca, nr 2, 1989, 7 .

Hamerska, Irena. „Cel - dalsza edukacja kobiet”, Nasza Praca, nr 3, 1980, 31-35.

Jackowska, Weronika. „Programowanie działań organizacji”, Nasza Praca, nr 6, 1980, 13-14, 26-27.

„Jak przybliżyć rzeczywiste równouprawnienie - spotkanie Prezydium ZG LKP z Wojciechem Jaruzelskim”, Nasza Praca, nr 7-8, 1989, 1.

Jaskółkowska, Regina. „Kronika wydarzeń”, Nasza Praca, nr 11, 1985, 32. Jaskółkowska, Regina. „Kronika wydarzeń”, Nasza Praca, nr 12, 1985, 32. Karwacka, Elżbieta. „Co nam pomaga, a co przeszkadza”, Nasza Praca, nr 3, 1989, 14-20.

Karwacka, Elżbieta. „Wczoraj i dziś”, Nasza Praca, nr 1, 1985, 9.

Kempara, Eugenia. „Przeciwko faszyzmowi - za pokojem i rozbrojeniem”, Nasza Praca, nr 4, 1980, 3-6.

Kempara, Eugenia. „VI Plenum KC PZPR”, Nasza Praca, nr 6, 1980, 3-10. „Kondycja gospodarstwa domowego - ważna dla całej gospodarki”, Nasza Praca, nr 7-8, 1989, 6-7.

„Kronika wydarzeń”, Nasza Praca, nr 4, 1980, 93-94.

Lewandowska, Romana. „Z historii ruchu kobiecego w Polsce. Sytuacja kobiet w Polsce w latach pięćdziesiatych", Nasza Praca, nr 4, 1985, 23-25. „Liga Kobiet Polskich w liczbach”, Nasza Praca, nr 4, 1989, 15. „Mało nas, mało nas radnych...”, Nasza Praca, nr 4, 1989, 28. 
Markowska, Danuta. „O wychowaniu dla przyszłości”, Nasza Praca, nr 3, 1980, 64-71.

„Materiały i dokumenty. Od Redakcji”, Nasza Praca, nr 9, 1985, 1-2.

Mroczek-Szymańska, Melania. „Kobiety polskie w zwycięstwie nad faszyzmem i w walce o pokój”, Nasza Praca, nr 4, 1980, 15-26.

„Notatki z posiedzenia ZG LKP”, Nasza Praca, nr 3, 1989, 4-5.

„Od Redakcji”, Nasza Praca, nr 1, 1980, 1-2.

„Od Redakcji”, Nasza Praca, nr 1, 1981, 1.

"Od redakcji”, Nasza Praca, nr 11, 1985, 1.

„Od redakcji”, Nasza Praca, nr 3, 1989, 1.

„Opinie Ligi Kobiet Polskich. Polityka socjalna PRL. Propozycje kierunków jej systemowych zmian", Nasza Praca, nr 2, 1989, 13-17.

Ostrowski, Dariusz. „Rok 1989”, Nasza Praca, nr 2, 1989, 3.

„Plenum Krajowej Rady Kobiet Polskich przy Ogólnopolskim Komitecie FJN.

Uchwała Krajowej Rady Kobiet Polskich”, Nasza Praca, nr 3, 1980, 7.

Polony, Janina. Trojnar, Danuta. „Informujemy, radzimy, pomagamy... Sekcja Kobiet Prawników. Rozmyślania o obowiazkach obywatelskich", $\mathrm{Na}$ sza Praca, nr 6, 1985, 38.

Porayski-Pomsta, Józef. „Poradnictwo językowe. Parlament i związane z nim słownictwo", Nasza Praca, nr 9-10, 1989, 29-32.

„Przegląd prasy”, Nasza Praca, nr 2, 1989, 40.

„Przegląd prasy”, Nasza Praca, nr 4, 1989, 45.

„Przegląd prasy”, Nasza Praca, nr 6, 1989, 43.

„Przegląd prasy”, Nasza Praca, nr 7-8, 1989, 44-46.

Regent-Lechowicz, Maria. „Wychowanie dla pokoju”, Nasza Praca, nr 4, 1980, 7-14.

„Sylwetki 40-lecia. Pamiętajmy o nich”, Nasza Praca, nr 1, 1985, 13.

Szczodrowska-Gasior, Małgorzata. „Kobiety w organach przedstawicielskich", Nasza Praca, nr 7-8, 1989, 16-18.

„Z pracy kół i zarządów”, Nasza Praca, nr 12, 1985, 31.

„Z pracy kół i zarządów”, Nasza Praca, nr 4, 1989, 42.

\section{Opracowania}

Ćwik, Urszula. „Wybory parlamentarne i wybory do rad narodowych w Polskiej Rzeczpospolitej Ludowej na łamach "Kobiety i Życia» (do 1989 roku)”, 
w: Małgorzata Dajnowicz, Adam Miodowski (red.), Polityka i politycy w prasie XX i XXI wieku, (Białystok: Wydawnictwo Humanica, 2016), 328-337. Dajnowicz, Małgorzata. „Zwierciadło” - platforma polityczna Ligi Kobiet w okresie PRL (1957-1961, 1982-1989)", Rocznik Historii Prasy Polskiej, t. 20, z. 3(47), 2017, 67-90.

Dajnowicz, Małgorzata. „Kobiety - polityka - wybory w świetle "Zwierciadła: Pisma Ligi Kobiet Polskich" (1982-1989)”, w: Grzegorz Radomski, Michał Strzelecki, Katarzyna Sopolińska (red.), Rzeczpospolita $w$ koncepcjach polskich partii $i$ środowisk politycznych XX $i$ XXI wieku, (Torun: Wydawnictwo Naukowe Uniwersytetu Mikołaja Kopernika, 2018), 107-125.

Dajnowicz, Małgorzata. „Liga Kobiet w terenie. Kierunki działalności organizacji na przykładzie struktur białostockich w latach 1966-1981", Niepodległość i Pamięć. Czasopismo humanistyczne, nr 2(62), 2018, 161-182.

Dajnowicz, Małgorzata. „Posłanki Ligi Kobiet Polskich i wybory parlamentarne 1989 roku (prezentacja w świetle "Zwierciadła")", w: Małgorzata Dajnowicz, Adam Miodowski (red.), Polityka i politycy w prasie XX i XXI wieku. Polityka w prasie kobiecej, (Białystok: Wydawnictwo Uniwersytetu w Białymstoku, 2019), 205-215.

Drozdowska, Agnieszka. „Działalność Ligi Kobiet w północno-wschodnich terenach Polski Ludowej w latach 1975-1989 w świetle "Naszej Pracy»", Niepodległość i Pamięć. Czasopismo humanistyczne, R. XXVI, nr 2(66), 2019, 183-211.

Jurkowska, Katarzyna. „Kłopoty z tożsamościa, czyli Liga Kobiet Polskich”, Ośka, nr 2, 2000, 38.

Marcinkiewicz-Kaczmarczyk, Anna. „Rola Ligi Kobiet w popularyzowaniu polityki władz "Polski Ludowej»", Dzieje Najnowsze, Vol 50, nr 2, 2018, 283-301.

Świętochowska, Emilia. „Sytuacja społeczno-zawodowa kobiet w ostatniej dekadzie PRL", w: Ewa Chabros, Agnieszka Klarman (red.), Kobiety na zakręcie 1933-1989, (Wrocław: IPN, 2014), 293-304.

\section{Strony internetowe}

Konstytucja Polskiej Rzeczypospolitej Ludowej z dnia 22.07.1952 r. [online] [dostęp: 3.07.2020]. Dostępna w World Wide Web: http://prawo.sejm. gov.pl/isap.nsf/download.xsp/WDU19520330232/O/D19520232.pdf. 